\begin{tabular}{|c|c|c|}
\hline CaM/产 & $\begin{array}{l}\text { Construction and Material Journal } \\
\text { e-ISSN 2655-9625, http://jurnal.pnj.ac.id/index.php/cmj }\end{array}$ & $\begin{array}{l}\text { Volume } 2 \text { No. } 3 \\
\text { November } 2020\end{array}$ \\
\hline
\end{tabular}

\title{
INITIAL GEOMETRIC IMPERFECTIONS AKIBAT TEKUK SINGLE CURVATURE MOMENT PADA BALOK BAJA SEDERHANA
}

\author{
Erlina Yanuarini ${ }^{1}$, Yanuar Setiawan ${ }^{2-}$, Tri Widya Swastika ${ }^{3}$ \\ 1,2,3 Politeknik Negeri Jakarta, Jurusan Teknik Sipil, Kukusan, Beji, Depok, 16425 \\ e-mail :erlina.yanuarini@sipil.pnj.ac.id, yanuar.setiawan@sipil.pnj.ac.id, \\ tri.widyaswastika@sipil.pnj.ac.id
}

\begin{abstract}
Steel beams are susceptible to initial geometric imperfections due to improper fabrication and installation processes. Consequently, long steel beams without stiffening are prone to bending due to lateral torsion. The purpose of this study is to determine the effect of variations in the initial geometric imperfections of Single Curvature-Moment (SCM) on the moment, total displacement, displacement in the $X$ direction (U1), displacement in the $Y$ direction (U2), and twist. This study used an $R H$ profile with a compact flange and web. The boundary condition used is a simple beam with an initial geometric imperfection due to single moment-curvature (SCM) bending. The variations used are the initial geometric imperfections values of SCM $0 \mathrm{~mm}$ (without initial geometric imperfections), SR5 (with initial geometric imperfections of $5 \mathrm{~mm}$ ), and SR10 (with initial geometric imperfections of $10 \mathrm{~mm}$ ). Initial geometric imperfections of SCM in steel beam decreased moment capacities up to more than $2 \%$ in elastic conditions and $12 \%$ in plastic states. This SR10 beam is also a beam that has a displacement of the $X$-axis $(U 1=-203,960 \mathrm{~mm})$, a displacement of the $Y$-axis $(U 2=-255,615 \mathrm{~mm})$, and the most significant twist $\left(28,179^{\circ}\right)$.
\end{abstract}

Keywords: buckle, initial geometric imperfections, Single Curvature-Moment

\section{ABSTRAK}

Balok baja rentan mengalami initial geometric imperfections akibat proses pabrikasi maupun pemasangan yang kurang tepat. Sementara balok baja yang panjang tanpa pengaku rentan mengalami tekuk akibat torsi lateral. Tujuan dari penelitian ini adalah untuk menentukan dampak variasi besarnya initial geometric imperfections Single Curvature-Moment (SCM) terhadap momen, displacement total, displacement arah $\mathrm{X}(\mathrm{U1})$, displacement arah $\mathrm{Y}(\mathrm{U} 2)$, dan twist. Penelitian ini menggunakan profil $\mathrm{RH}$ dengan sayap dan badan yang kompak. Boundary condition yang digunakan adalah balok sederhana dengan initial geometric imperfections akibat tekuk single momen curvature (SCM). Variasi yang digunakan adalah besarnya nilai initial geometric imperfections SCM 0 mm (tanpa initial geometric imperfections), SR5 (dengan initial geometric imperfections $5 \mathrm{~mm}$ ), dan SR10 (dengan initial geometric imperfections $10 \mathrm{~mm}$ ). Dari hasil penelitian diketahui bahwa pada kondisi elastis, leleh, maupun plastis, balok dengan initial geometric imperfections SCM menunjukkan penurunan kapasistas momen mengalami penurunan hingga mencapai lebih dari $2 \%$ pada kondisi elastis dan $12 \%$ pada kondisi plastis. Balok SR10 juga merupakan balok yang memiliki displacement arah sumbu X (U1=-203,960 $\mathrm{mm})$, displacement arah sumbuY $(U 2=-255,615 \mathrm{~mm})$, dan twist yang paling paling besar $\left(28,179^{\circ}\right)$.

Kata kunci: tekuk, initial geometric imperfections, Single Curvature Moment 


\section{PENDAHULUAN}

Profil $\mathrm{H}$ atau I beam sering digunakan sebagai balok struktur utama dari suatu bangunan maupun jembatan [1],[2].

Balok bentang panjang tanpa pengaku lateral $\left(L_{b}>L_{r}\right)$ rentan mengalami lateral torsional buckling. Panjang balok tanpa pengaku lateral dinamakan panjang tanpa di-bresing $\left(L_{b}\right)$. Dimana $L_{r}$ adalah suatu batasan tentang tekuk torsi lateral kondisi inelastic (plastis) tanpa adanya pengaku [3]. Semakin panjang balok baja maka ketidaksepurnaan geometri awal (initial geometric imperfections) dari struktur tersebut pada saat pabrikasi sangat mungkin terjadi [4]. Hal tersebut kadang tidak bisa dihindari, sehingga diperlukan analisis khusus untuk melihat pengaruhnya terhadap momen nominal dan displacement akibat ketidaksempurnaan geometri tersebut.

Ketidaksempurnaan awal pada balok baja akibat tekuk oleh momen-momen ujung yang sama pada kondisi elastis membuat suatu balok I tidak dapat mencapai momen lelehnya [5]. Momen nominal pada batas tekuk torsi lateral biasanya lebih kecil dari momen nominal lentur pada keadaan batas leleh [6]. Adapun persamaan untuk mencari nilai momen nominal lentur menurut menurut SNI 1729-2015 dapat dilihat melalui persamaan berikut ini:

$$
\begin{aligned}
& M_{n}=M_{p}=Z_{x} F_{y} \\
& M_{y}=F_{y} \cdot S_{x}
\end{aligned}
$$

Ketidaksempurnaan awal pada balok baja akibat tekuk oleh momen-momen ujung yang sama juga membawa pengaruh pada displacement baik itu dalam arah vertikal, arah horizontal, maupun arah longitudinal, maupun rotasi pada sumbu $\mathrm{Z}$ (twist) seperti dalam penelitian yang dilakukan oleh Dermihan, dkk [7]. Adapun bentuk ketidak sempurnaan awal baik berupa ketidaklurusan awal $\left(u_{0}\right)$ maupun twist $\left(\gamma_{0}\right)$ awal pada suatu balok [8],[9] ditunjukkan pada Gambar 1.

$$
\begin{aligned}
& u_{0}=\delta_{0} \cdot \sin \frac{\pi z}{L} \\
& \gamma_{0}=\theta_{0} \cdot \sin \frac{\pi z}{L} \\
& E I_{y} \frac{d^{2} u}{d z^{2}}+\left(\gamma+\gamma_{0}\right) M_{0}=0 \\
& G J \frac{d \gamma}{d z}-\left(\frac{d u}{d z}+\frac{d u_{0}}{d z}\right) M_{0}=0 \\
& \frac{\delta_{0}}{\theta_{0}}=\frac{\left(M_{0}\right)_{c r}}{\left(\frac{\pi^{2} E I_{y}}{L^{2}}\right)}
\end{aligned}
$$

Single curvature-moment terjadi karena adanya beban momen di kedua ujung suatu balok yang besar dan arahnya sama-sama membentuk suatu displacement tunggal (single curvature) [10].Untuk dapat meminimalisir besarnya biaya produksi yang ditimbulkan akibat sering adanya produk yang gagal karena adanya ketidak sempurnaan dari suatu struktur profil tertentu, akibat pengaruh dari initial geometric imperfections dari suatu struktur perlu dianalisis [6],[11],[12]. Ketidaksempurnaan awal pada balok baja juga akan membawa pengaruh pada rotasi balok tersebut di sepanjang bentang. Jadi, tujuan dari penelitian ini adalah untuk menentukan dampak variasi besarnya initial geometric imperfections Single Curvature-Moment (SCM) terhadap kapasitas momen, displacement arah X (U1), displacement arah Y (U2), dan twist.

\section{METODE PENELITIAN}

Penelitian ini merupakan penelitian analisis dengan bantuan software finite element ABAQUS [13]. Profil balok baja yang digunakan sebagai model adalah $\quad R H 708 \times 302 \times 15 \times 28$ dengan mutu baja $E=210000 M P a$, $v=0,3$ dengan kekuatan leleh $F_{y}=$ $345 M P a$ dan $F_{y}=513 M P a$. Adapun data material untuk kondisi elastis yang 
digunakan adalah data material pada kondisi real yang didapatkan dari hasil pengujian material di lapangan, seperti yang digunakan pada penelitian sebelumnya [9],[14]. Balok baja dengan profil $\quad R H 708 \times 302 \times 15 \times 28$ dimodelkan dalam bentuk solid. Perilaku initial geometric imperfections dalam bentuk single curvature moment didapatkan dari analisis buckle dengan beban $M$ yang sama besar nilainya di ujung-ujung baloknya. Dalam penelitian ini boundary condition yang digunakan adalah boundary condition pertama (BC1), nilai $\mathrm{U} 1=0 ; \mathrm{U} 2=0$; $\mathrm{U} 3=0$ di $\mathrm{RP} 1$; dan UR3=0, sedangkan untuk boundary condition kedua (BC2), nilai $\mathrm{U} 1=0$; U2=0; dan UR3=0 di RP2. RP1 dan RP2 adalah titik pusat profil RH di ujungujung baloknya, seperti tampak pada Gambar 1. Boundary condition yang digunakan pada Tahap 1 dan Tahap 2 adalah sama.

Panjang balok untuk ketiga model dalam penelitian ini sama sebesar $\mathrm{L}=10 \mathrm{~m}$. Variasi yang digunakan dalam penelitian ini adalah besar initial geometric imperfections akibat tekuk single moment curvature yaitu sebesar $0 \mathrm{~mm}, 5$ $\mathrm{mm}$, dan $10 \mathrm{~mm}$. Dalam perencanaan balok baja, initial geometric imperfections yang diijinkan adalah 1/1000 panjang balok baja diantara 2 tumpuan tanpa pengaku $\left(L=L_{b}\right)$ [15]. Artinya jika panjang model yang digunakan adalah $10 \mathrm{~m}$, maka maksimum initial geometric imperfections-nya adalah $10 \mathrm{~mm}$. Variasi model yang digunakan dalam model dapat diketahui melalui Tabel 1. Ketentuan sumbu axis yang digunakan dalam penelitian ini, untuk arah 1 mewakili sumbu $X$, arah 2 mewakili sumbu Y, dan arah 3 mewakili sumbu Z [13] seperti yang ditunjukkan dalam Gambar 2.

Analis tahap pertama dengan metode analisis buckle menggunakan beban awal yang diberikan sebesar $\mathrm{M} 1=1 \mathrm{di}$ RP1 dan $M=-1$ di RP2 dalam satuan $\mathrm{N}$ dan mm untuk menentukan besar Eigen value. Eigen value sangat diperlukan dalam analisis buckle karena dapat memodelkan mode shape suatu model struktur [6],[12],[16]. Pada analisis tahap pertama menggunakan properties elastis dari profil baja tersebut. Setelah didapatkan nilai Eigen value maka nilai Eigen value tersebut diinputkan sebagai beban momen M1 di RP1 dan M2 di RP2 dengan metode analisis statis risk dengan menyertakan initial geometric imperfections-nya $(\mathrm{NLGEOM}=\mathrm{ON})$ [17]. Pada analisis tahap kedua menggunakan properties material elastis dan juga plastis. Penelitian yang sama menggunakan statis risk juga pernah dilakukan sebelumnya untuk mendapatkan perilaku kondisi inelastis pada pipa baja berlubang akibat adanya nonlinear geometry [18].

Batasan masalahnya dalam penelitian ini adalah:

1. Initial geometric imperfections yang digunakan berbentuk single curvature moment untuk model SR5 dan SR10 dan tumpuan sendi rol (balok sederhana)

2. Hanya membandingkan sumbu kuat (M1) pada kondisi elastis $\left(2 \% M_{p}\right)$, leleh $\left(M_{y}\right)$, dan plastis $\left(M_{p}\right)$.

3. Displacement total (U), displacement arah X (U1), displacement arah Y (U2), dan twist (rotasi) dibahas hanya sampai balok SR0 mencapai $M_{p}$.

4. Balok baja yang digunakan tanpa diberikan pengaku lateral

Jadi, penerapan variasi tersebut diharapkan dapat mengetahui bagaimana pengaruh initial geometric imperfections tersebut terhadap momen arah sumbu kuat (M1), displacement arah 1 (U1), displacement arah 2 (U2), dan twist (rotasi) pada balok sederhana.

\section{HASIL dan PEMBAHASAN}

Analisis tahap pertama buckle akibat single moment curvature menghasilkan bentuk initial geometric imperfections 
seperti pada Gambar 3.a. Pada Gambar 3.b dan Gambar 3.c menggambarkan U1 dan U2 di sepanjang bentang pada ujung atas profil dengan bentuk initial geometric imperfections yang sama, tetapi dengan besaran yang berbeda, yaitu $5 \mathrm{~mm}$ untuk SR5 dan $10 \mathrm{~mm}$ untuk SR10 mm. Berdasarkan hasil di atas, dapat diketahui bahwa untuk initial geometric imperfections SCM menghasilkan displacement arah U1 lebih besar dari pada arah U2. Besar displacement awal U1 pada ujung kanan sayap profil lebih kecil dibandingkan dengan besar displacement awal U1 pada ujung kanan bawah sayap profil. Hal ini terjadi karena adanya beban momen yang searah dan sama besar dengan analisis tekuk (buckle).

Analisis tahap pertama dengan step buckle menghasilkan Eigen value sebesar 2,3559 $\times 10^{9}$ dengan input beban dan material dalam satuan $\mathrm{N}$ dan mm. Eigen value diinputkan sebagai beban saat analisis buckle step static risk.

\section{Kapasitas Momen Nominal}

Profil balok $R H 708 \times 302 \times 15 \times 28$ merupakan profil yang mempunyai badan kompak dan sayap kompak. Panjang profil balok adalah $L_{b}=10 \mathrm{~m}$, sedangkan batasan untuk panjang tanpa pengaku untuk tekuk torsi lateral adalah $L_{r}=8,333 \mathrm{~m}$. Bila $L_{b}>L_{r}$ maka perhitungan momen nominal lentur $\left(M_{n}\right)$ akibat tekuk torsi lateral harus diperhitungan. Hasil perhitungan matematis tanpa adanya initial geometric imperfections, momen nominal pada kondisi plastis adalah sebesar $\quad M_{n}=M_{p}=7344 \mathrm{~cm}^{3} \times$ $345 \mathrm{MPa}=2534 \mathrm{kNm}$ dan saat terjadi leleh pertama kali pada serat terluar sebesar $\quad M_{n}=M_{y}=6504 \mathrm{~cm}^{3} \times$ $345 \mathrm{MPa}=2244 \mathrm{kNm}$.

Analisis dengan software finite element diperoleh dari tahap analisis kedua, step static risk. Kapasitas momen balok baja dalam kondisi elastis $\left(2 \% M_{p}\right)$, leleh $\left(M_{y}\right)$, dan plastis $\left(M_{p}\right)$ disajikan dalam Tabel 2. Dari Tabel 2 diketahui bahwa bila balok tanpa initial geometric imperfections single curvature moment (SR0) pada kondisi elastis $M 1=2 \% M_{p}$ mempunyai momen sebesar 506,73 $\mathrm{kNm}$. Sedangkan balok dengan initial geometric imperfections $5 \mathrm{~mm}$ (SR5) mempunyai momen sebesar 500,6 kNm $(1,210 \%)$. Balok dengan initial geometric imperfections $10 \mathrm{~mm}$ (SR0) mempunyai momen sebesar $482,2 \mathrm{kNm}$ $(2,867 \%)$.

Pada kondisi leleh, balok SR0 memiliki momen sebesar $2244 \mathrm{kNm}$, sesuai dengan perhitungan matematisnya. Sedangkan balok SR5 memiliki momen sebesar 2211,5 kNm (1,448\%) dan balok SR5 memiliki momen sebesar 2196,3 kNm (2,126\%). Pada kondisi plastis ketika balok tanpa initial geometric imperfections SR0 memiliki momen sebesar $2244 \mathrm{kNm}$ yang besarnya sama dengan nilai $M_{p}$. Sedangkan balok SR5 hanya memilili momen maksimum/ultimate sebesar 2227,36 $\operatorname{kNm}(1,448 \%)$ dan balok SR10 memiliki momen ultimate sebesar 2215,39 $\mathrm{kNm}$ $(2,126 \%)$.

Pada kondisi elastis kapasistas momen untuk balok dengan initial geometric imperfections SCM menunjukkan penurunan yang relatif kecil (5\%), selaras dengan penelitian yang sebelumnya untuk balok dalam kondisi elastis [6]. Serupa dengan kondisi tersebut, untuk kondisi leleh, kapasitas momen dengan initial geometric imperfections SCM juga menunjukkan penuruan yang relatif kecil (kurang dari 5\%). Namun pada kondisi leleh, balok dengan initial geometric imperfections SR5 dan SR10 tidak mampu mencapai momen lelehnya, terlebih momen plastisnya. Penurunan momen juga terlihat signifikan yaitu sebesar $12 \%$ (lebih dari 10\%) untuk balok dengan initial geometric imperfections SCM. Perbedaan besar initial geometric 
imperfections tidak menunjukkan efek yang signifikan jika dibandingkan hasil M1 untuk balok SR5 dan SR10. Sehingga dengan Batasan maksimum initial geometric imperfections $1 / 1000 \mathrm{~L}$ untuk kondisi elastis, kapasitas momen dengan initial geometri tersebut masih bisa dikatakan cukup bagus pada kondisi elastis sebelum terjadinya buckle, namun tidak pada kondisi plastis. Balok SR10 mengalami penurunan momen kapasitas yang lebih besar daripada SR5, dengan adanya initial geometric imperfections sebesar $10 \mathrm{~mm}$. Dari ketiga kondisi, baik elastis, leleh, maupun plastis, balok dengan initial geometric imperfections SCM menunjukkan penurunan kapasistas momen.

\section{Displacement Arah Sumbu X (U1) dan Sumbu Y (U2)}

Titik (node) di ujung kanan bawah dari penampang profil $R H 708 \times 302 \times$ $15 \times 28$ digunakan untuk menunjukkan pengaruh displacement maksimum, karena pada ujung tersebut mengalami displacement yang paling besar. Gambar 4.a menunjukkan momen arah sumbu kuat (M1) terhadap displacement arah X (U1) baik pada kondisi plastis maupun elastis untuk ketiga model balok. Titik acuan yang digunakan untuk penyajian data, diambil pada titik(node) di ujung sayap kanan bawah yang terletak di tengah bentang $\left(\frac{1}{2} L\right)$. Balok tanpa initial geometric imperfections (SR0) memiliki nilai $\mathrm{U} 1=0$ baik pada kondisi elastis maupun plastis (Gambar 5). Sehingga dapat dikatakan bahwa balok SR0 tidak mengalami displacement arah sumbu $\mathrm{X}$ (U1) yang artinya pada balok tersebut tidak terjadi twist (rotasi). Sedangkan pada balok dengan initial geometric imperfections SCM (SR5 dan SR 10) mempunyai displacement pada arah sumbu X (U1) baik pada kondisi elastis maupun kondisi plastis (Gambar 5).

Pada kondisi elastis balok SR0 mempunyai nilai $\mathrm{U} 1=-0,019 \mathrm{~mm}, \mathrm{SR} 5$
$=-0,852 \mathrm{~mm}$, dan SR10 mempunyai nilai $\mathrm{U} 1=-1,687 \mathrm{~mm}$ (paling maksimum). Pada kondisi plastis, U1 sangat terlihat besar sekali perbedaannya balok dengan initial geometric imperfections, untuk SR0 U1 $=-0,463$ $\mathrm{mm}$, sedangkan SR5 U1 $=202,335 \mathrm{~mm}$ dan SR $10 \mathrm{U} 1=203,960 \mathrm{~mm}$ (lihat Tabel 5). Balok SR10 dengan initial geometric imperfections sebesar $10 \mathrm{~mm}$, mempunyai displacement arah sumbu $\mathrm{X}$ (U1) yang paling besar. Jadi adanya initial geometric imperfections pada suatu balok memberikan pengaruh yang cukup signifikan pada displacement arah sumbu X (U1).

Gambar 4.b dan Gambar 6 menunjukkan bahwa pada momen yang sama misalnya $506,73 \mathrm{kNm}$ (kondisi elastis) terlihat bahwa untuk balok SR10 (13,318 mm) memiliki nilai U2 yang lebih lebih besar dari pada balok SR5 $(13,181 \mathrm{~mm})$ dan SR0 $(13,058 \mathrm{~mm})$, namun tidak signifikan perbedaannya. Begitu pula saat M1 SR0 mencapai leleh pertama kali $\left(M_{y}\right)$ dan M1 SR5 dan M1 SR10 mencapai ultimate $\left(M_{c r}\right)$ (Gambar 6), perbedaan yang terjadipun tidak signifikan. Namun ketika dalam kondisi plastis, perbedaan U2 terlihat cukup signifikan (lihat Gambar 6). Balok SR5 memiliki displacement U2 yang lebih besar daripada balok SR0 (tanpa initial geometric imperfections SCM). Jadi, initial geometric imperfections SCM juga memperbesar displacement U2 pada suatu balok dalam kondisi elastis, terlebih pada kondisi elastis.

\section{Rotasi Pada Sumbu Z (Twist)}

Twist yang dianalisis dalam penelitian berada di tengah bentang $\left(\frac{1}{2} L\right)$. Twist diketahui dari besar displacement yang ada di tengah sayap atas profil balok, dibandingkan dengan displacement di tengah sayap bawah profil balok, seperti yang terlihat pada Gambar 7. 
Namun karena balok dimodelkan dalam bentuk solid extrusion, sulit mendapatkan nilai tepat di ujung tengahnya, karena berdampak pada konvergensi saat analisis. Nilai displacement di tengah profil atas balok diperoleh dari nilai displacement ratarata di kiri dan di kanan sayap atas profil balok. Perhitungan yang sama juga diberikan untuk balok yang berada di sayap bawah. Hubungan antara momen dengan twist tampak pada Gambar 8.

Gambar 8 menunjukkan bahwa seiring dengan meningkatnya momen, maka twist untuk balok dengan initial geometric imperfections SCM (SR5 dan SR10) dalam analisis tekuk lebih besar dari pada balok tanpa initial geometric imperfections (SR0). Seperti yang terlihat pada Gambar 9, pada kondisi elastis, twist SR0 $=0^{\circ}$, twist SR5 = $0,042^{\circ}$, twist $\mathrm{S} 10=0,086^{\circ}$. Saat SR0 mencapai leleh pertama kali, twist $\mathrm{SR} 0=$ 0,006, sementara twist SR5 $=0,342^{\circ}$, twist $\mathrm{S} 10=0,433^{\circ}$ saat mencapai ultimate. Pada kondisi plastis ketika M1 SR0 mencapai $M_{p}$, maka dihasil twist SR0 $=-0,038^{\circ}$, sedangkan twist $\mathrm{SR} 5=27,371^{\circ}$ dan twist SR10=28,179 . Tanda minus di sini hanya menunjukkan arah sumbu yang berlawanan. Jika minus artinya ke samping kiri dan positif ke samping kanan. Balok dengan initial geometric imperfections SCM memiliki twist yang semakin membesar saat M1 membesar, terlebih lagi saat melampaui momen kritis maksimumnya $M_{c r}$. Balok SR10 dengan initial geometric imperfections sebesar $10 \mathrm{~mm}$, mempunyai twist $(\gamma)$ yang paling besar dibandingkan dengan balok SR0 dan SR5. Dari Gambar 10.a, 10.b 10.c terlihat dengan jelas perbedaan ketiga model saat kondisi plastis (gambar dengan skala tertentu). Jadi initial geometric imperfections SCM memperbesar twist pada balok baik pada kondisi elastis, terlebih lagi pada kondisi plastis.

\section{KESIMPULAN}

Pada kondisi elastis, leleh, maupun plastis, balok dengan initial geometric imperfections SCM menunjukkan penurunan kapasistas momen hingga mencapai lebih dari $2 \%$ pada kondisi elastis dan $12 \%$ pada kondisi plastis. Dari ketiga model balok, balok SR10 dengan initial geometric imperfections sebesar $10 \mathrm{~mm}$, memiliki penurunan kapasistas momen yang lebih besar dibandingkan dengan balok SR0 dan SR5. Balok SR10 juga merupakan balok yang memiliki displacement arah sumbu $\mathrm{X}$ (U1), displacement arah sumbuY (U2), dan juga twist yang paling paling besar.

\section{DAFTAR PUSTAKA}

[1] T. V. Galambos and A. E. Surovek, Structural Stability of Steel: Concepts and Applications for Structural Engineers. 2008.

[2] J. P. S. de Oliveira, A. F. G. Calenzani, R. H. Fakury, and W. G. Ferreira, "Elastic critical moment of continuous composite beams with a sinusoidal-web steel profile for lateral-torsional buckling," Eng. Struct., vol. 113, pp. 121-132, 2016, doi: 10.1016/j.engstruct.2016.01.021.

[3] Badan Standardisasi Nasional, SNI 1729: Spesifikasi untuk bangunan gedung baja struktural Badan Standardisasi Nasional. Jakarta, 2015.

[4] F. Papp, "Buckling assessment of steel members through overall imperfection method," Eng. Struct., vol. 106, pp. 124-136, 2016, doi: 10.1016/j.engstruct.2015.10.021.

[5] Z. Kala, "Elastic lateral-torsional buckling of simply supported hot-rolled steel I-beams with random imperfections," Procedia 
Eng., vol. 57, pp. 504-514, 2013, doi:

10.1016/j.proeng.2013.04.065.

[6] M. Šorf and M. Jandera, "Lateral-torsional buckling of slender cross-section stainless steel beams," Structures, vol. 28, no. December 2019, pp. 14661478, 2020, doi: 10.1016/j.istruc.2020.09.073.

[7] A. L. Demirhan, H. E. Eroğlu, E. O. Mutlu, T. Yılmaz, and Ö. Anil, "Experimental and numerical evaluation of inelastic lateral-torsional buckling of Isection cantilevers," J. Constr. Steel Res., vol. 168, 2020, doi: 10.1016/j.jcsr.2020.105991.

[8] W. F. Chen and E. M. Lui, Structural Stability, Theory and Implementation. New York, 1987.

[9] E. Yanuarini and : Cheng-Cheng Chen, "The Effects of Initial Imperfection Shapes to Steel Beam Behavior," National Taiwan University of Science and Technology, 2012.

[10] A. Samanta and A. Kumar, "Distortional buckling in monosymmetric I-beams," ThinWalled Struct., vol. 44, no. 1, pp. 51-56, 2006, doi: 10.1016/j.tws.2005.09.007.

[11] M. R. Karamooz Ravari et al., "On the effects of geometry, defects, and material asymmetry on the mechanical response of shape memory alloy cellular lattice structures," Smart Mater. Struct., vol. 25, no. 2, 2016, doi: 10.1088/0964-1726/25/2/025008.

[12] S. Novoselac, T. Ergić, and P. Baličević, "Linear and nonlinear buckling and post buckling analysis of a bar with the influence of imperfections," Teh.
Vjesn., vol. 19, no. 3, pp. 695701, 2012.

[13] Simulia Dassault Systèmes Corp, Abaqus Analysis User's Manual. 2016.

[14] Y. Bu and L. Gardner, "Local stability of laser-welded stainless steel I-sections in bending," $J$. Constr. Steel Res., vol. 148, pp. 49-64, 2018, doi: 10.1016/j.jcsr.2018.05.010.

[15] American Institute of Steel Construction, Specification for Structural Steel Buildings. Chicago, 2010.

[16] C. N. Thombare, K. K. Sangle, and V. M. Mohitkar, "Nonlinear buckling analysis of 2-D coldformed steel simple cross-aisle storage rack frames," J. Build. Eng., vol. 7, pp. 12-22, 2016, doi: 10.1016/j.jobe.2016.05.004.

[17] F. H. Abed, M. H. AlHamaydeh, and S. A. Barakat, "Nonlinear Finite-Element Analysis of Buckling Capacity of Pretwisted Steel Bars," J. Eng. Mech., vol. 139, no. 7, pp. 791-801, 2013, doi: $10.1061 /($ asce)em.19437889.0000528 .

[18] A. Franus and Ł. Kowalewski, "An efficiency comparison of numerical implementation approaches of hyperelastic constitutive model in ABAQUS/Standard," in MATEC Web of Conferences, 2018, vol. 196, pp. 0-7, doi: $10.1051 /$ matecconf/20181960105 2. 
Tabel 1. Variasi Model Penelitian

\begin{tabular}{cllc}
\hline Model & Simbol & Variabel tetap & $\begin{array}{c}\text { Variabel berubah }=\text { besar initial geometric } \\
\text { imperfections akibat buckle single moment } \\
\text { curvature }\end{array}$ \\
\hline 1 & SR0 & Boundary condition, & $\mathrm{U}=0 \mathrm{~mm}$ \\
2 & SR5 & beban, Eigen value & $\mathrm{U}=5 \mathrm{~mm}$ \\
3 & SR10 & & $\mathrm{U}=10 \mathrm{~mm}$ \\
\hline
\end{tabular}

Tabel 2. Kapasitas Momen dalam Kondisi Elastis, Leleh, dan Plastis

\begin{tabular}{|c|c|c|c|c|c|c|}
\hline Model & $\begin{array}{c}\mathrm{M} 1 \\
\text { (elastis) } \\
\mathrm{kNm}\end{array}$ & $\begin{array}{l}\text { Perbedaan M1 (elastis) } \\
\%=\frac{M 1_{S R O e}-M 1_{S R e}}{M 1_{S R 0 e}}\end{array}$ & $\begin{array}{l}\text { M1 } \\
\text { (leleh) } \\
\text { kNm }\end{array}$ & $\begin{array}{l}\text { Perbedaan M1 (leleh) } \\
\%=\frac{M 1_{S R 0 y}-M 1_{S R y}}{M 1_{S R 0 y}}\end{array}$ & $\begin{array}{c}\mathrm{M} 1 \\
\text { (plastis) } \\
\mathrm{kNm}\end{array}$ & $\begin{array}{l}\begin{array}{c}\text { Perbedaan M1 } \\
\text { (plastis) }\end{array} \\
\% \quad \frac{M 1_{S R 0 p}-M 1_{S R p}}{M 1_{S R O p}}\end{array}$ \\
\hline SR0 & 506,73 & $0,000 \%$ & 2244,00 & $0,000 \%$ & 2534,27 & $0,000 \%$ \\
\hline SR5 & 500,60 & $1,210 \%$ & 2211,50 & $1,448 \%$ & 2227,36 & $12,111 \%$ \\
\hline SR10 & 492,20 & $2,867 \%$ & 2196,30 & $2,126 \%$ & 2215,39 & $12,583 \%$ \\
\hline
\end{tabular}

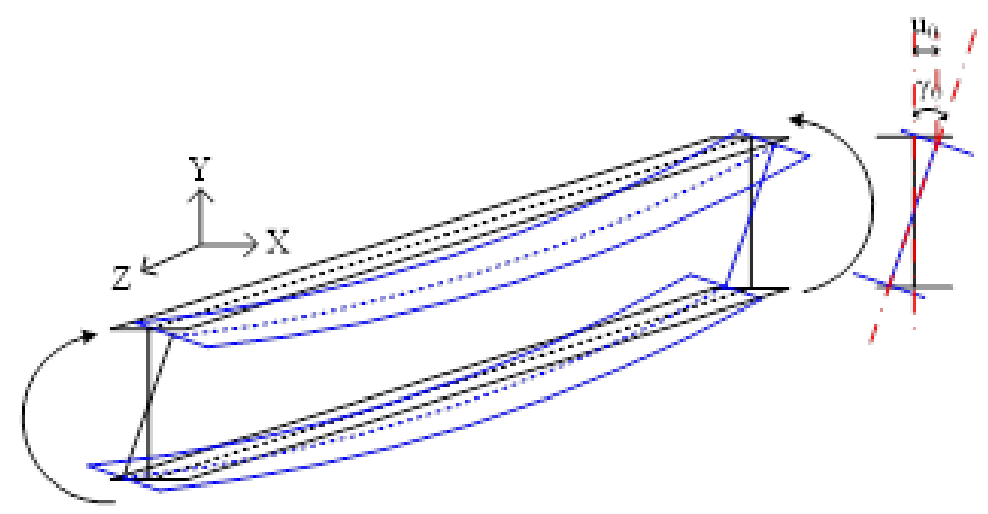

Gambar 1. Initial geometric imperfections $\left(\mathrm{u}_{0}\right)$ dan initial twist $\left(\gamma_{0}\right)$ pada balok

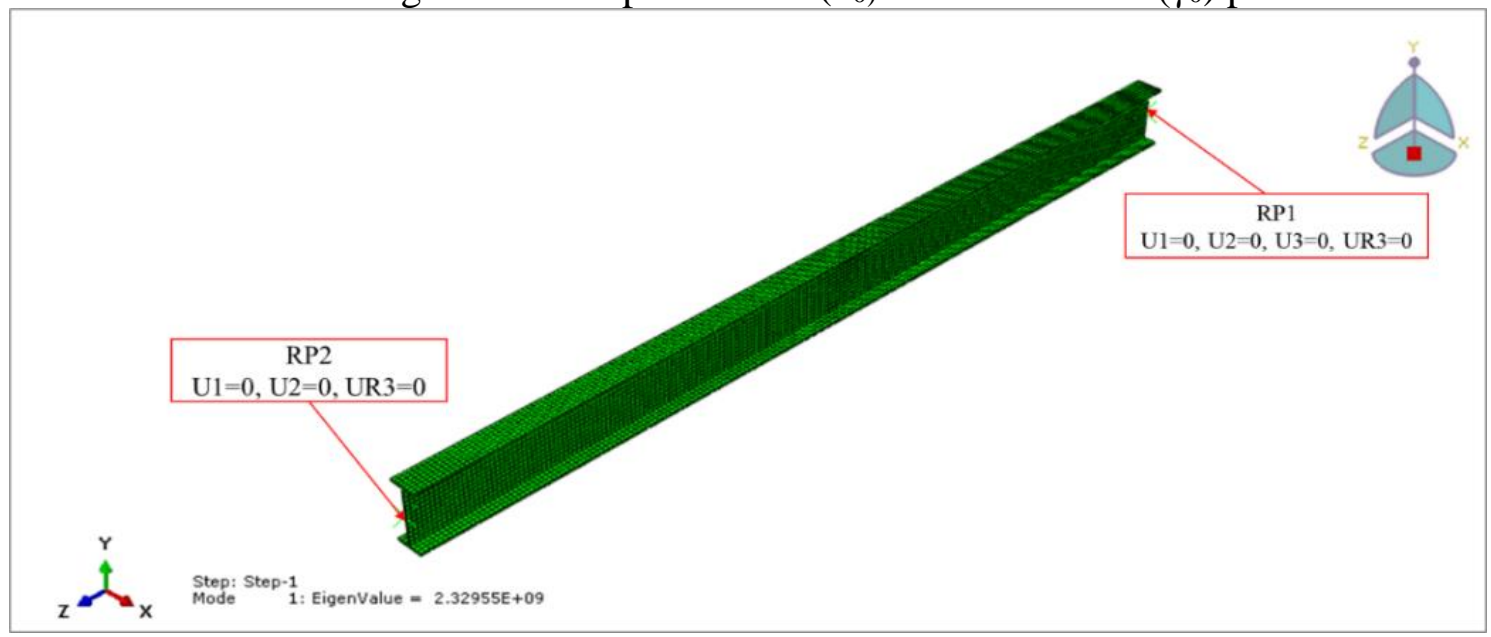

Gambar 2. Gambar Balok Sederhana dengan Boundary Condition-nya 

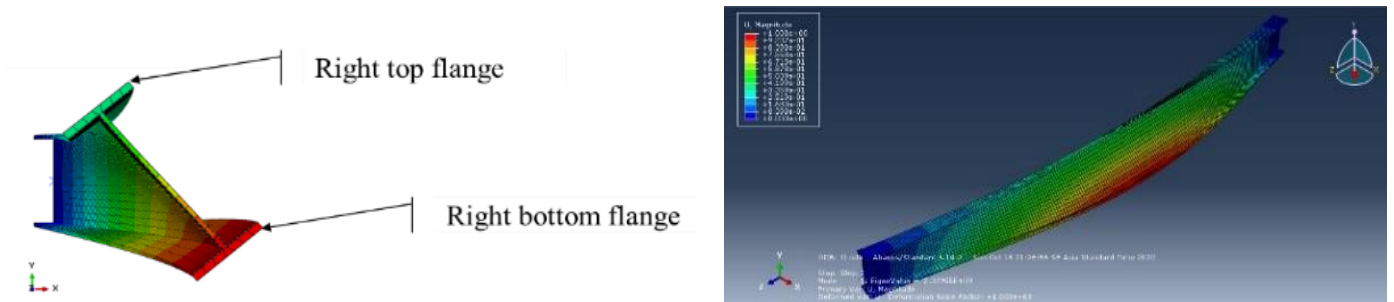

(a)

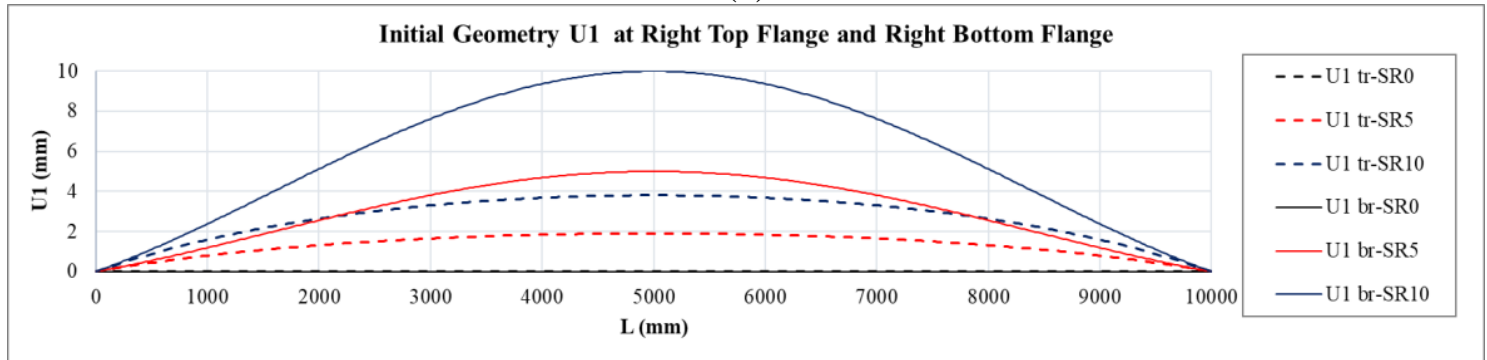

(b)

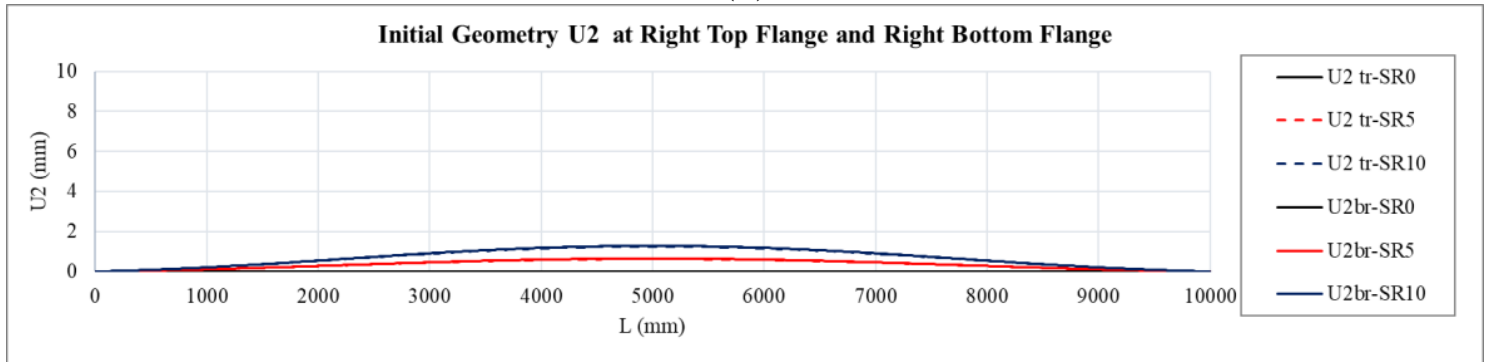

(c)

Gambar 3.a Gambar Initial geometric imperfections SCM, 3.b Initial geometric imperfections Single Curvature-Moment (U1, U2) di Kanan Atas Sayap Profil, 3.c Initial geometric imperfections Single Curvature-moment (U1, U2) Kanan Bawah Sayap Profil

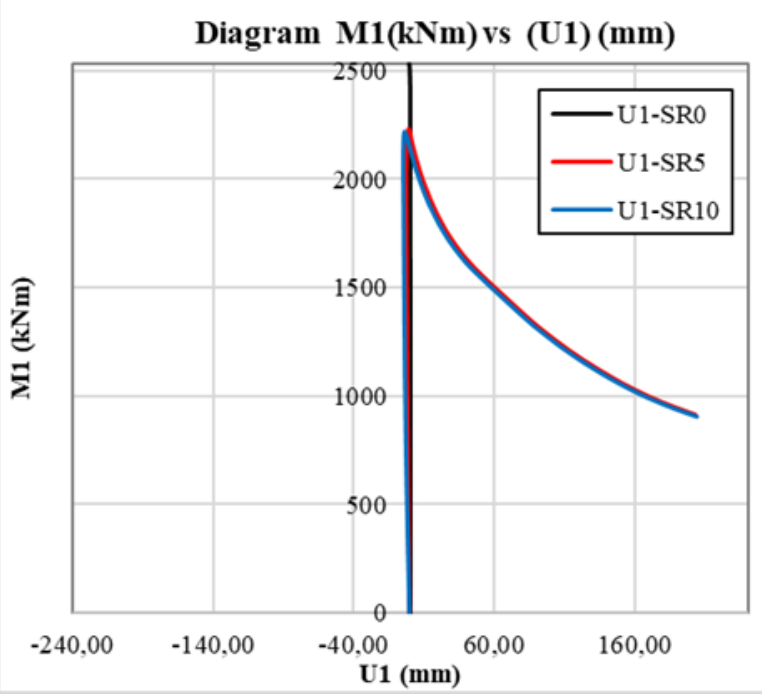

(a)

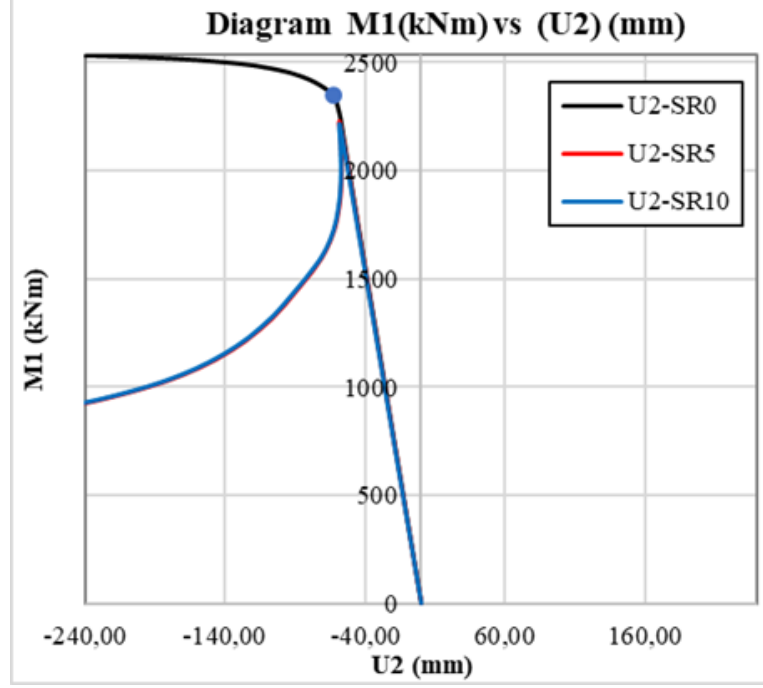

(b)

Gambar 4.a Diagram Momen Arah Sumbu Kuat (M1) vs U1, 4.b Diagram Momen Arah Sumbu Kuat (M1) vs U2 


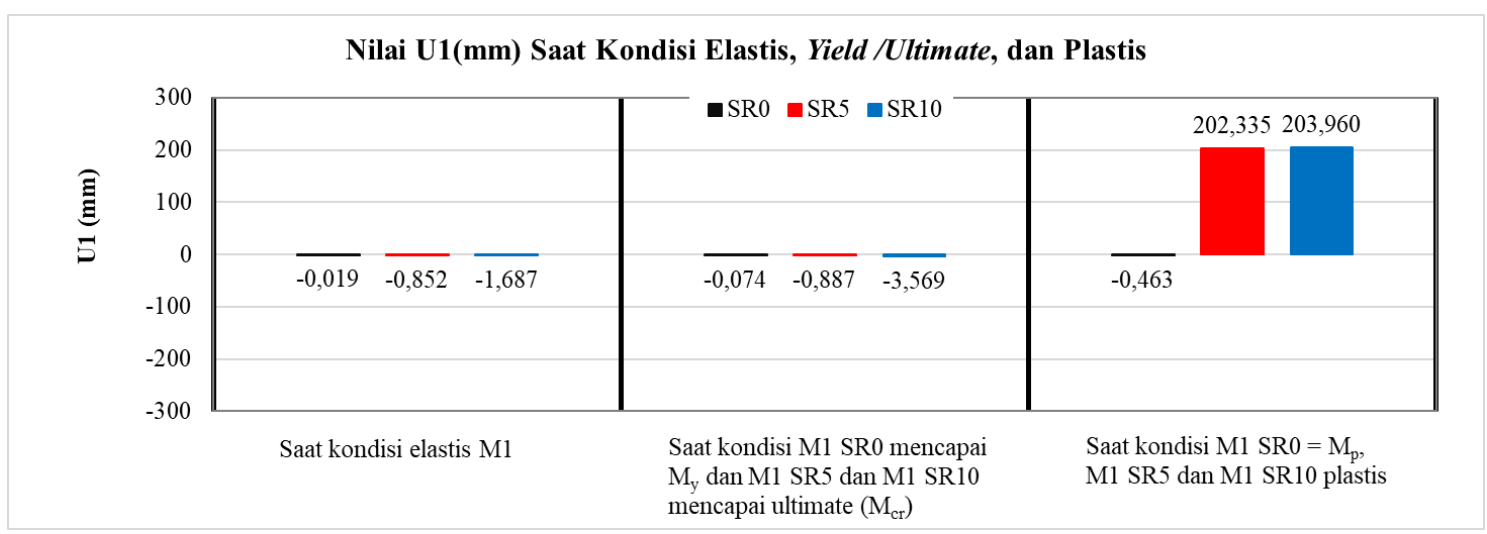

Gambar 5. Nilai U1 (mm) Saat Kondisi Elastis, Yield/Ultimate, dan Plastis

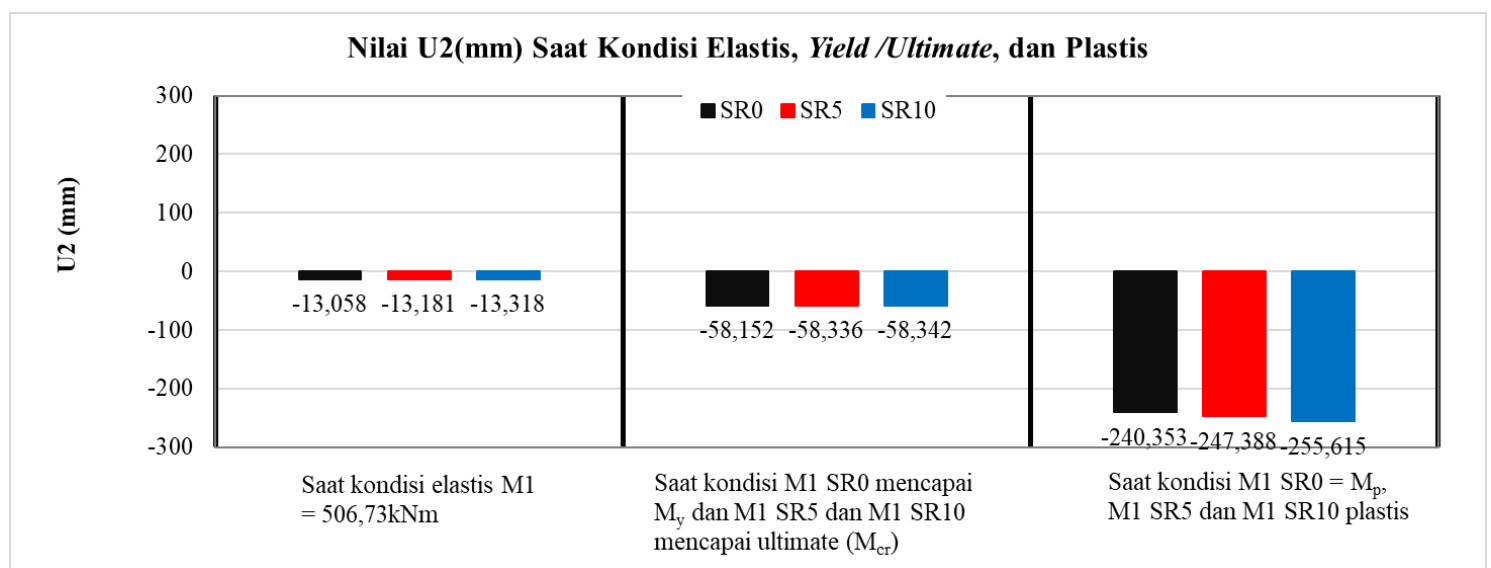

Gambar 6. Nilai U2 (mm) Saat Kondisi Elastis, Yield/Ultimate, dan Plastis

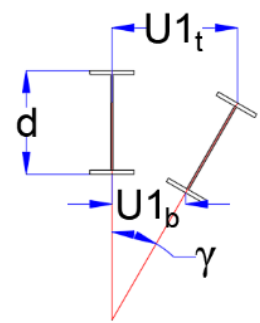

Gambar 7. Twist $(\gamma)$ pada Profil

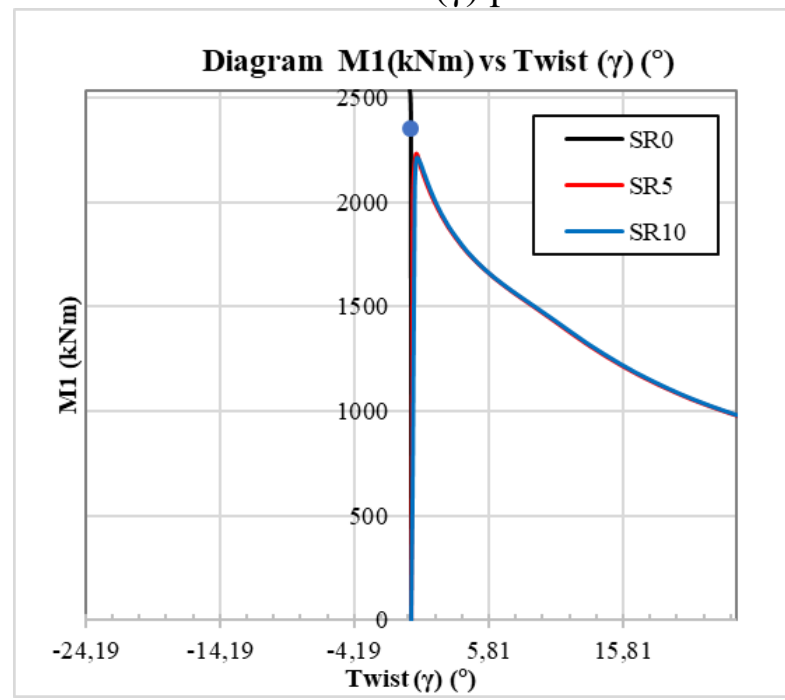

Gambar 8. Diagram Momen Arah Sumbu Kuat (M1) vs Twist $(\gamma)$ 
Twist $\left({ }^{\circ}\right)$ Saat Kondisi Elastis, Yield /Ultimate, dan Plastis

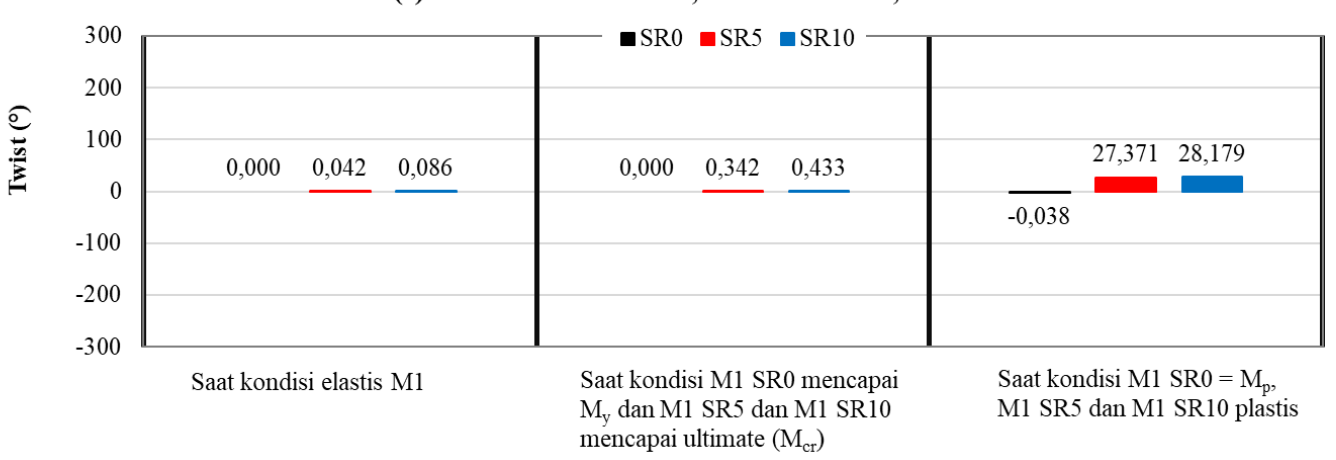

Gambar 9.Twist $\left(^{\circ}\right)$ Saat Kondisi Elastis, Yield/Ultimate, dan Plastis

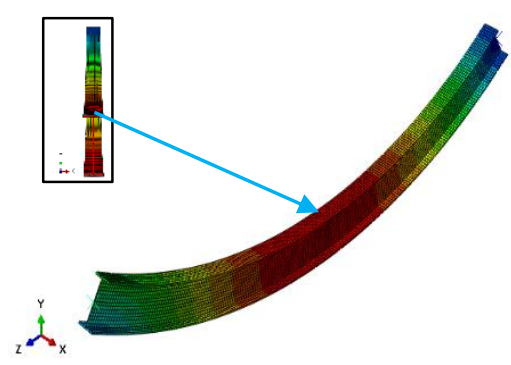

(a)

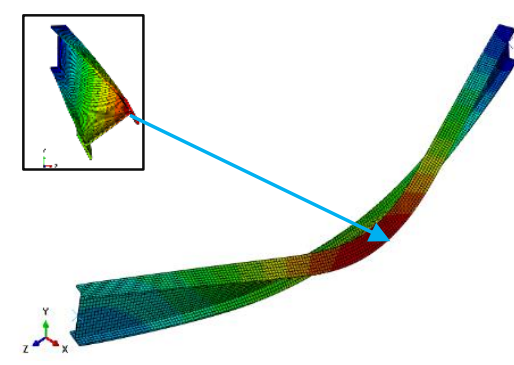

(b)

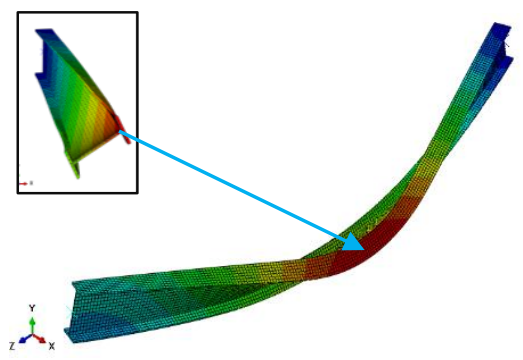

(c)

Gambar 10.a Displacement Balok SR0; 10.b Displacement Balok SR5; 10.c Displacement Balok S10 